\title{
OGIVES OF THE FORBES TYPE ON ALPINE GLACIERS AND A STUDY OF THEIR ORIGINS
}

\author{
By JOEL E. Fisher \\ (New York)
}

\begin{abstract}
Ogives form beneath active ice falls whose heads are situated near or below the firn line. They consist of curved bands of alternating white, bubbly, less dense ice and darker, denser ice with fewer bubbles, extending throughout the thickness of the glacier. The difference in character is held to be due to the different conditions in the upper ice fall, through which the ice passes in one year at high speed. In summer the thin and shattered ice is exposed to high temperatures and melt water, while in winter the conditions are of Arctic-type throughout the thickness of the attenuated ice. A lane of ice on the Gornergletscher, originating as cold, dry snow with no melt water present, illustrates the character and origin of the white bubbly ice. The greater elevation of this cold-snow ice and the waves formed beneath the ice falls are considered to be the result of the lesser thermal conductivity and greater albedo of the white bubbly ice.
\end{abstract}

RÉst'mé. Les ogives se forment en aval d'une chute de glace active dont le début est situé près ou endessous de la ligne de névé. Elles consistent en bạndes courbes de glace alternativement blanche, bulleuse, moins dense, et plus sombre, plus dense, moins bulleuse, s'étendant à travers la masse du glacier. La différence de caractère semble être due aux conditions différentes règnant dans la partie supérieure de la chute de glace à travers laquelle la glace passe à grande vitesse en une année: durant l'été, la glace mince et délabrée est exposée à de fortes températures et à l'eau de fonte, alors qu'en hiver les conditions sont du type arctique pour toute la masse de glace atténuée. Une laisse de glace du Glacier du Gorner, formée de neige froide et sèche sans eau de fonte, illustre le caractère et l'origine de la glace bulleuse blanche. La plus grande altitude de cette glace de neige froide et les vagues formées en-dessous de la chute de glace sont considérées comme le résultat d'une moindre conductivité thermique et d'une plus grande albédo de la glace bulleuse blanche.

Zusammenfassing. Ogiven entstehen unterhalb von aktiven Gletscherbrüchen, deren obere Teile nahe der Firnlinie oder unter ihr liegen. Sie bestehen aus gekrümmten Bändern, die abwechselnd aus weissen, blasenreichen, weniger dichtem Eis und dunklerem, dichteren Eis mit weniger Luftblasen bestehen. Die Bänder erstrecken sich auf die ganze Dicke des Gletschers. Die charakteristischen Unterschiede sind, wie man annimmt, auf die verschiedenen Verhältnisse im oberhalb gelegenen Eisbruch zurückzuführen, durch den das Eis im Laufe eines Jahres mit grosser Geschwindigkeit durchfliesst. Im Sommer ist das dünne und zerrüttete Fis hohen Temperaturen und der Wirkung von Schmelzwasser ausgesetzt, während im Winter über die ganze Dicke des dünner gewordenen Eises arktische Verhältnisse herrschen. Am Gorner Gletscher illustriert ein Eisstreifen, der aus kaltem, trockenen Schnee entstanden ist und kein Schmelzwasser aufweist, den Charakter und den Ursprung des weissen blasenreichen Lises. Die Erhebung dieses aus Kaltschnee entstandenen Eises über das andere Eis und die unter dem Eisbruch gebildeten Wellen werden als Frgebnis der geringeren Wärmeleitung und des grösseren Albedo des weissen blasenreichen Eises angesehen.

\section{INTRODUCTION}

I hope that whoever reads this will also read the superb article on ogive formation by Dr. C. A. M. King and Mr. W. V. Lewis (196I), both for its analysis, for its illustrations, and for its references. That artic e on the Austerdalsbreen ogives appeared after I had already put together, for presentation on 21 April 1961 before the American Geophysical Union, a ${ }_{1} 6 \mathrm{~mm}$. movie film of the ogives of the Mer de Glace, of the Arolla and of the Trift Glaciers in the Alps, with background material bearing on their origins. This paper is based on the points made in the movie film. It is my hope that the interleaving of my own observations of alpine ogives with the British party's observations of Norwegian ogives, and especially the application of related features of the unique lane of white ice on the Gornergletscher at Zermatt, may give a sufficiently generalized understanding of these beautiful creations of nature, definitely to explain their origin.

\section{DESCRIPTION}

Ogives are striking cross-glacier bands of alternate white and dark ice, curved downglacier, normally spaced some 200 to $500 \mathrm{ft}$. (60-1 $50 \mathrm{~m}$.) apart. They repeat each other indefinitely along the glacier so that an ogived glacier reminds the observer from a distance of the striped back of a rattlesnake. Ogived glaciers are relatively rare. (See Figures 1, 2, 3 and 4 , p. 54 and 55.) They were first described by Forbes in 1842 and have been studied time and 


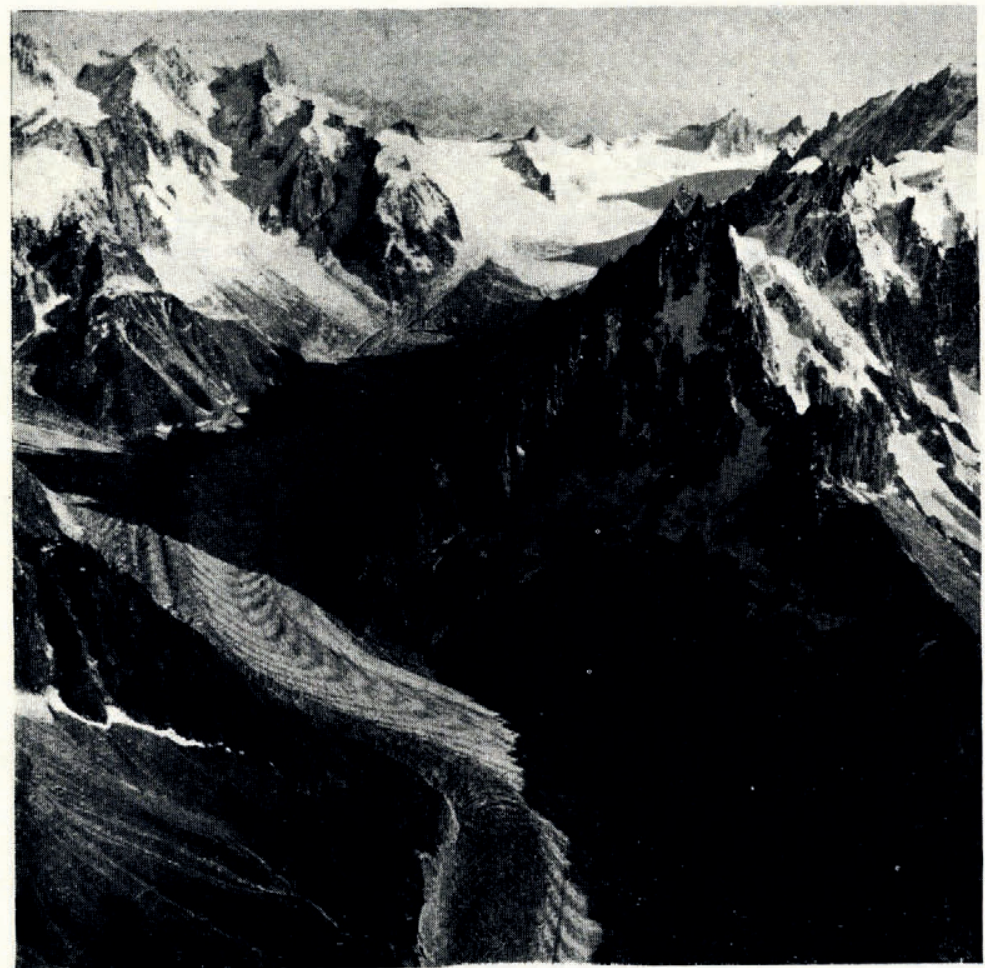

Fig. I. Mer de Glace ogives, from airplane over snout. There are today 70 ogives on it. Forbes's map in 1842 shows 42 ogives on it. Photograph by H. Geiger (Sion) 1960

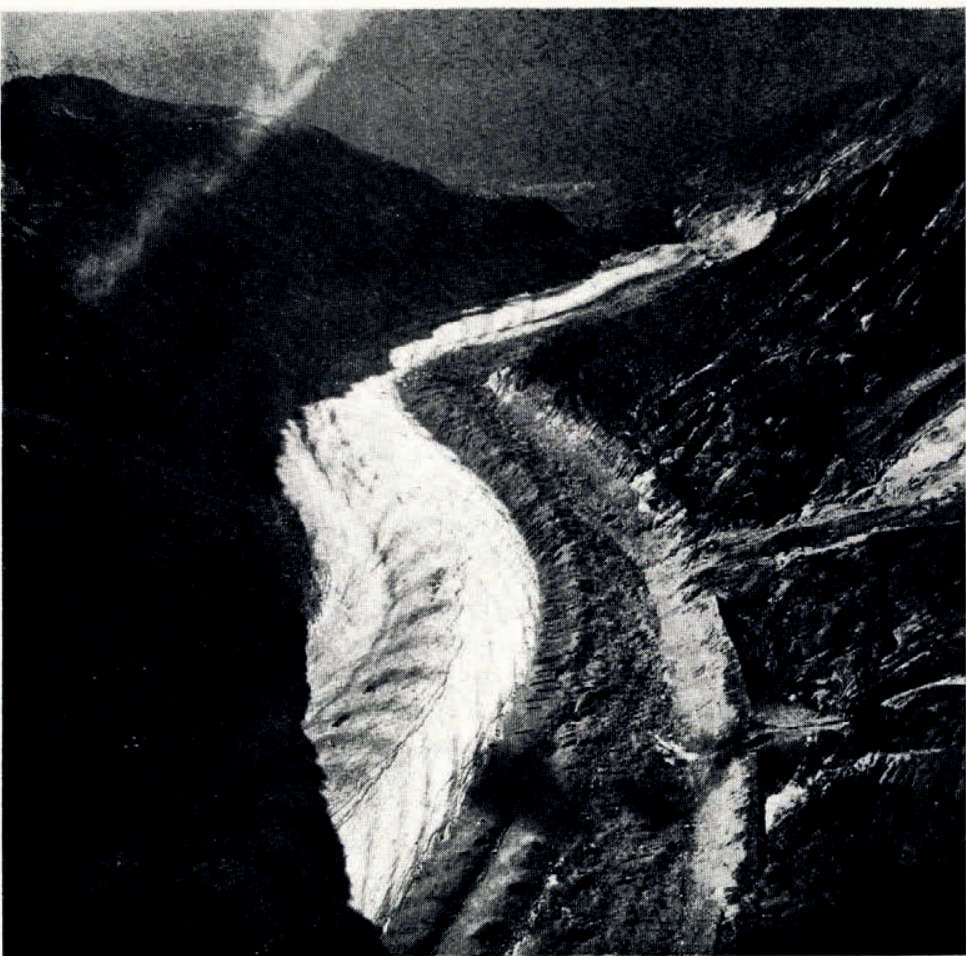


Fig. 3. Mer de Glace ice fallhardened avalanche debris here masks the earliest waves. Photograph by H. Geiger (Sion) 1959
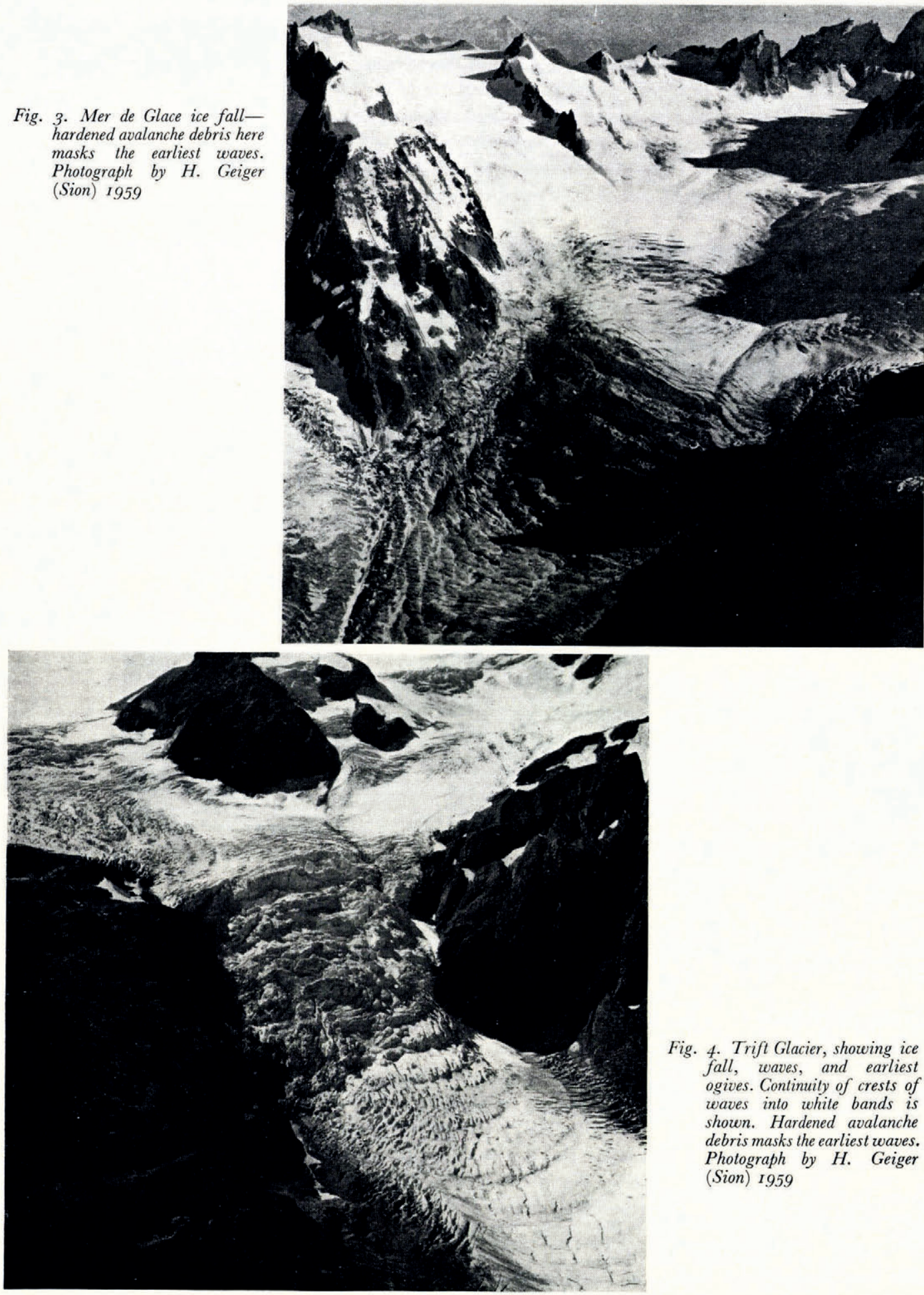

Fig. 4. Trift Glacier, showing ice fall, waves, and earliest ogives. Continuity of crests of waves into white bands is shown. Hardened avalanche debris masks the earliest waves. Photograph by $\mathrm{H}$. Geiger (Sion) 1.959 
again since then. All classical explanations have seemed unsatisfactory to me, and I have been studying them during the last 40 years.

Any explanation must satisfy six features of these bands, namely:

(1) They occur only on certain temperate glaciers and only below extremely active ice falls, and they repeat continuously from the foot of the ice fall to the very snout of the glacier.

(2) Their spacing is substantially one-year's flow of the glacier.

(3) The ice in each white band area is predominantly bubbly ice, density about $0 \cdot 89 \mathrm{~g} . / \mathrm{cm} .{ }^{3}$, typical of the Arctic. The ice in the dark band area is predominantly free of air bubbles,

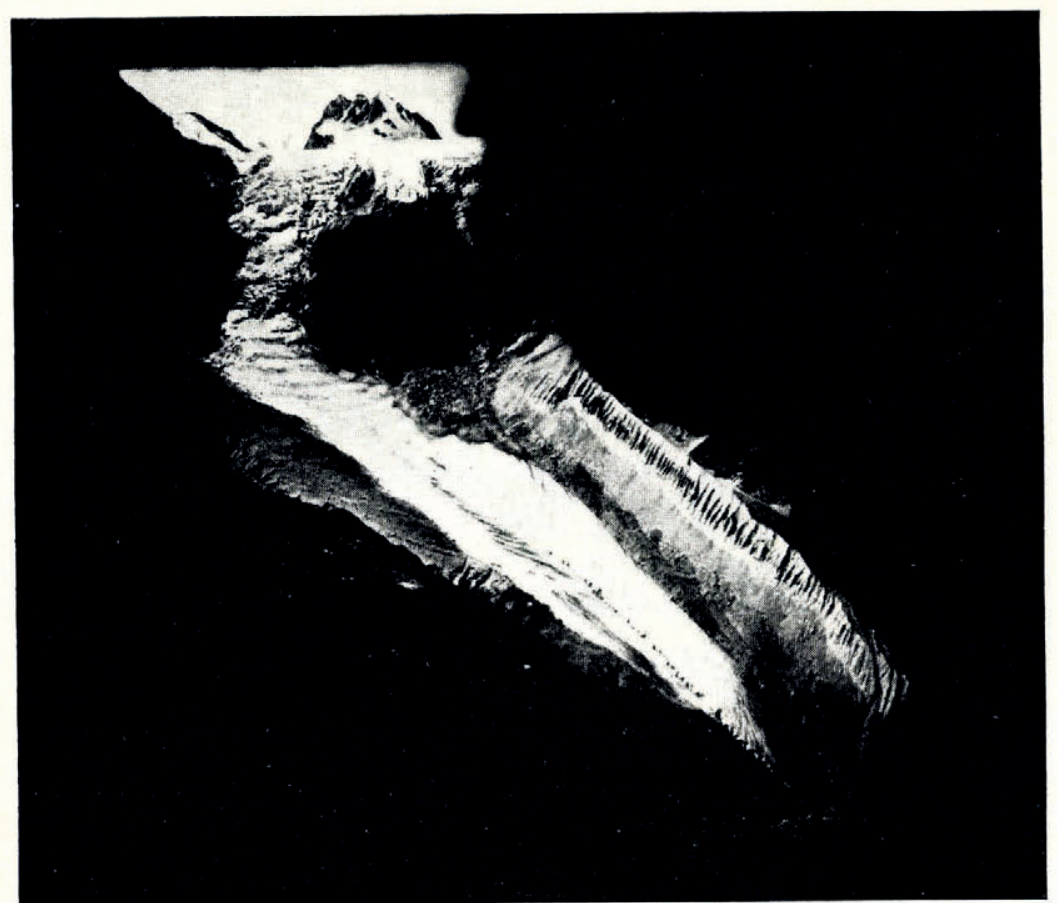

Fig. 5. The . Lrolla Glacier, showing ice fall. waze, and ogives, extending continuously to its very snout. Photograph by Felix Julen ( Zermatt) $194^{6}$

density about $0 \cdot 91 \mathrm{~g} . / \mathrm{cm}^{3}$, typical of temperate glaciers. Bubbly ice, being whiter to the eye than bubble-free ice, causes the characteristic banding effect to the eye even when there is no dirt present on the dark bands. If some dirt exists on the white bubbly ice, it tends to be hidden from other than vertical observation. It is concentrated at the bottom of countless, shallow, little dust wells (Kryokonitlöcher) (Fig. 9), thus preserving to the observer the apparent whiteness of the white bands.

(4) The two types of ice, bubbly and non-bubbly, continue vertically down through the structure of the glacier to its very bed. The ogive structure is no mere surface feature.

(5) At the foot of the ice fall, before the ogives develop their striking contrasts, there appears a series of low cross-glacier waves like great ocean swells (see Figures 4 and 6). As these waves move down-glacier, their diminishing crests are soon replaced by the white bands and their troughs by the dark bands of the ogives.

(6) The head of the ice fall generating the waves and ogives is itself always near or below the firn line.

Care must be taken not to confuse these striking Forbes bands with the outcrop of annual 
néré layering, sedimentary in type, a phenomenon which occurs more and more often as one goes further north.

\section{Observations in Norway}

Dr. King and Mr. Lewis ( $196 \mathrm{I}$ ) cite the extreme attenuation of the ice of the glacier when in rapid transit through the ice fall proper, as exposing such ice during the summer to more than normal sun and rain-factors which would produce larger crystal growth in ice traveling down through the ice fall in summer than in ice traveling down it in winter.

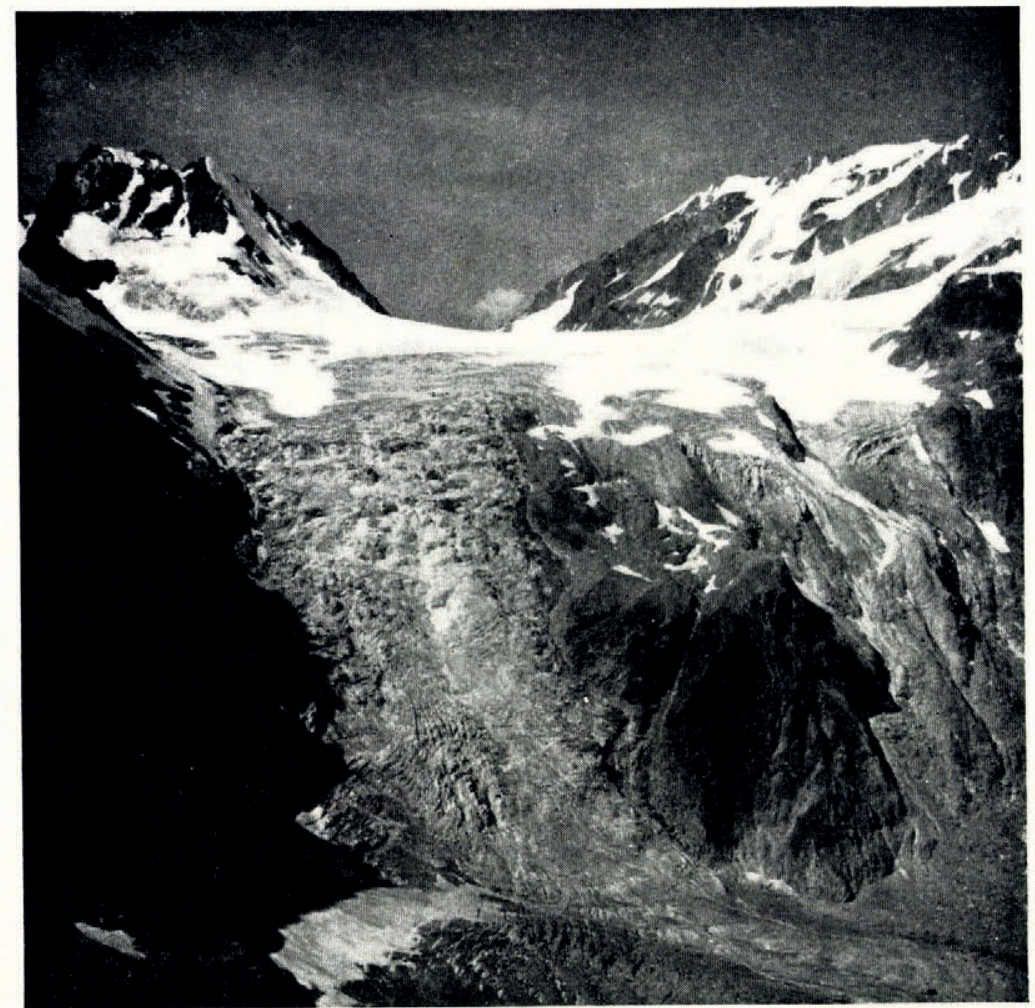

Fïg. 6. Irolla Glacier, showing ice fall. waves, and earliest ogives. Contimuity of crests of waies into white bands is shown. Pholograph by Henri Viunnier (.1rolla) 1.95 .9

\section{Observations in the Alps}

With this I wholeheartedly agree - in fact, Figures 3, 4 (p. 55) and 6 from the Alps suggest that extreme attenuation. "A fast-sliding slab of crushed ice" (Dr. King), is, in my opinion, a considerable understatement. I would say that ice, in rushing at speed down the ice fall, is not only attenuated as to its actual thickness, but is completely shattered by cracks and crevasses, smashed up, and a large part is actually pulverized through avalanching and re-avalanching down hill and is even turned over, like soil in a garden, so that the "ice fall" ice, throughout its entire thickness, quickly finds itself exposed almost completely to ambient air temperatures, summer or winter. This is particularly true of the beginning area of an ice fall, as will be described below.

In summer, the effect is just as described by King and Lewis. But in winter, it is my clear conclusion that this ice fall ice, far more than just being "unexposed to melt water", as implied 
by King and Lewis, is under the influence of Arctic-type conditions throughout its depth, well below $0^{\circ} \mathrm{C}$.

This refrigeration at depth contrasts with the temperate glacier winter cold wave penetration of barely io $\mathrm{m}$.

It is of critical importance to note that the time of passage through the active area of an ice fall for all three Swiss ogive-producing ice falls is of the order of one year. The velocity of ice in that most active, upper part of these three ice falls is of the order of 10 to 20 times that of the flat glacier above or below the ice fall. This, of course, means that the ice thickness in this upper area is relatively very thin. I presume that this same difference, referred to as found in Austerdalsbreen, applies in the same way, only to the upper "active" area of Austerdalsbreen.

This "active" portion of the ice fall is by no means the entire region of a highly crevassed glacier, all of which ranks as "ice fall" to the mountain climber. This "most active" portion of the ice fall is merely the uppermost portion of the drop-the area immediately below the first great ice cliff, perhaps one-third of the total "drop".

\section{The Process}

Thus, while in summer the ice-of-passage debouches from the ice fall into the outrunning flat glacier as completely temperate ice with melt water present and reconsolidates as one would expect, into nearly bubble-free temperate ice, density about $0.9 \mathrm{I} \mathrm{g} . / \mathrm{cm} .{ }^{3}$, - the story is quite different in winter. Ice-of-passage debouching in winter into the outrunning flat glacier comes out at temperatures well below freezing, and reconsolidates as would a massive accumulation of cold snow with no melt water present. It is in fact bubbly ice, density about $0.89 \mathrm{~g} . / \mathrm{cm} .{ }^{3}$. In both summer and winter, the sudden retardation of velocity of the moving ice fall ice, as it levels off into the wider flat glacier, compels immediate consolidation, just as a wet-snow spring avalanche, or a powder-snow avalanche in winter, slushing down its run, consolidates instantly, when it is halted by the valley floor, into hard snow, snow so hard that a victim is caught in it as in a vise.

\section{Relation of Gorner Lane of White Ice}

This cold snow consolidation process is of peculiar reality to me. On the Gornergletscher (Fig. 7) there is a unique central lane of white bubbly ice, density about 0.89 to $0.87 \mathrm{~g} . / \mathrm{cm} .{ }^{3}$. It is the triangular central lane which wedges out in the foreground. I described it at length in the Journal of Glaciology ( I 950), but I hasten to repeat a correction (already noted) that the source of accumulation of this white lane is not the avalanche deb is from cliffs of the Nordend of Monte Rosa overhanging the Gornergletscher's upper reaches. Actually, this lane of white bubbly ice has its source in the cold, sunless north slopes up against the Silbersattel, between the Dufourspitze and the Nordend. It is the firnification of that accumulation under cold conditions, with almost never any presence of melt water, which produces that perfection of white bubbly ice, density $0.87 \mathrm{~g} . / \mathrm{cm} .{ }^{3}$, in the Gornergletscher's white lane. Incidentally, this white lane rides io to $20 \mathrm{~m}$. higher than the level of normal, more solid, darker ice on both flanks (see Fig. 8, p. 59). Another feature is the tendency of all the surface dirt on this "white lane" to concentrate at the bottom of countless tiny dust wells (Kryokonitlöcher) (Fig. 9, p. 59). This is typical of all bubbly ice areas.

The softness of mid-day summer snow, even at high altitudes in the Alps, everywhere except in those rare, exceptionally cold and nearly sunless regions such as the Silbersattel area of Monte Rosa, attests to the presence of melt water almost daily in summer in typical areas of accumulation which are the source of the much commoner nearly bubble-free ice of all temperate glaciers.

Here then, in the sharp segregation between bubbly white ice, density $0.87 \mathrm{~g} . / \mathrm{cm} . .^{3}$, and 
Fig. 7. The lane of white bubbly ice, wedging out between the flanking darker areas of the Gorner Glacier. This white lane originates up between the two highest summits cutting down through the Nordend cliffs by a poorly discernible gorge about $2.5 \mathrm{~cm}$. from top of photo, $3.7 \mathrm{~cm}$. from left margin of photograph (1952)
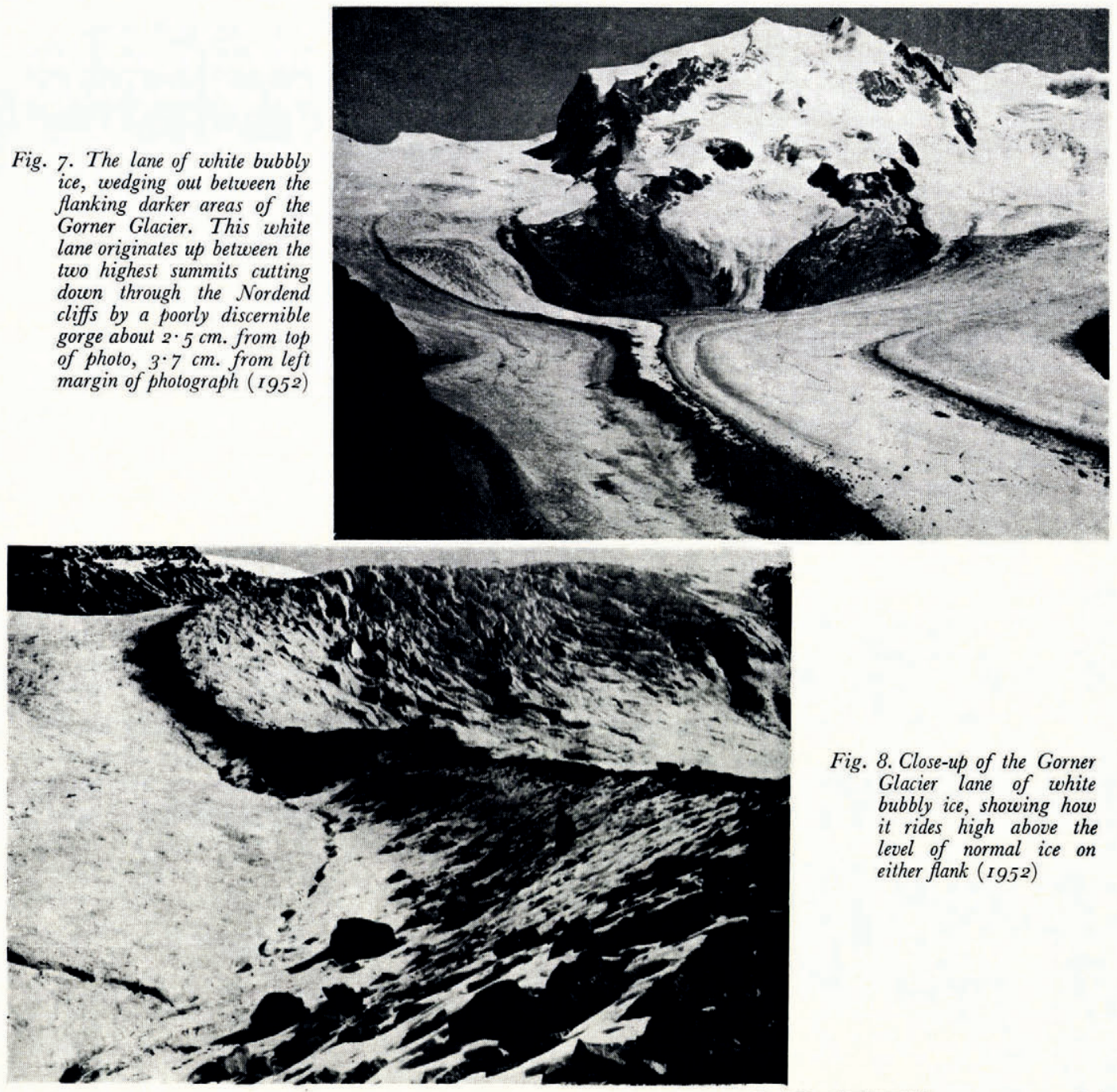

Fig. 8. Close-up of the Gorner Glacier lane of white bubbly ice, showing how it rides high above the level of normal ice on either flank ( 19.52 )

Fig. 9. Dust wells in bubbly ice. Boot at right shows scale (1952)

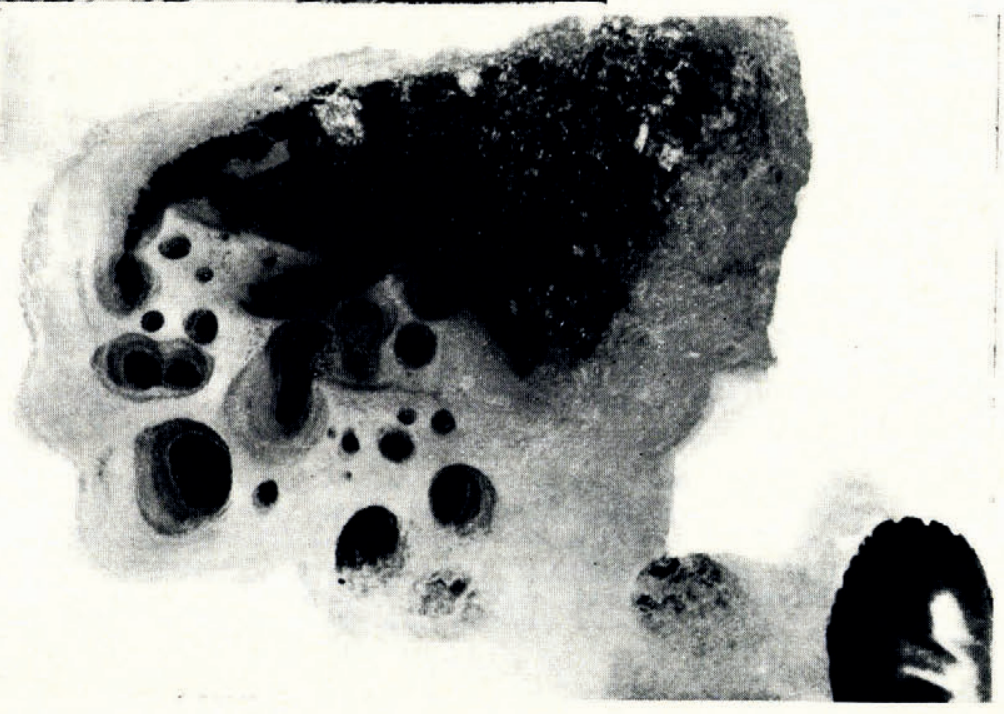


normal more bubble-free ice, density $0.9^{\mathrm{I}} \mathrm{g} . / \mathrm{cm} \cdot{ }^{3}$, the white lane and the flanking darker ice areas of the Gornergletscher can be seen as clues to the origin of the light and dark bands of ogives.

In both cases, the white bubbly ice, density $0 \cdot 89-0 \cdot 87 \mathrm{~g} . / \mathrm{cm} .{ }^{3}$, traces its origin to the consolidation or firnification of cold dry snow or pulverized ice under temperatures cold enough to prohibit the presence of melt water. In both cases, the darker, nearly bubble-free ice, density about $0.9^{1} \mathrm{~g} . / \mathrm{cm} .^{3}$, traces its origin to areas of consolidation or firnification often above the freezing point with melt water present.

The occasional narrow bands of darker ice, foliated into the white bands of ogives, obviously are the compressed survivors of former seracs or blocks of ice in the ice fall which survived, unbroken, through all the shattering movement. Similarly, occasional filaments of white bubbly ice, sometimes found cutting the dark bands, bespeak former crevasses (opened, however, below the ice fall) which were filled with cold winter snow, after passage through the ice fall.

The waves themselves (see particularly Figs. 4 and 6) - whose crests are reconcilable down-glacier a short distance with white bands - attest the close relationship of the white bands to the white lane of the Gorner. Both the white lane of the Gorner and the white band areas ride above the level of the normal darker ice. I have no demonstrable explanation, but I suspect it is due to the very considerably lesser thermal conductivity of bubbly ice compared with that of normal ice, and with its greater albedo (difference of specific gravity seems totally insufficient). The extreme example of such resistance to ablation appears to be the extraordinary white "Ice Ships" of many Himalayan glaciers-remnants after ablation of the far greater Himalayan white ice lanes. These, as individual spires of white ice, may tower $30 \mathrm{~m}$. or more above the general glacier. (I have measured in support the comparative thermal conductivities of the two types of ice, in the field, and found that the thermal conductivity of the bubbly ice, density $0.87 \mathrm{~g} . / \mathrm{cm}^{3}{ }^{3}$, was approximately one-half that of nearly bubblefree ice. See footnote.)

\section{Descriplion of field experiments:}

1. Measuring density of "solid" and "bubbly" ice:

Take a straight sided pail, partly full of water, as near 39 F. $\left(3.9^{\circ}\right.$ (.) as convenient.

Measure its depth, $1_{1}$.

Submerge in that water a block of ice whose density is to be measured.

Holding that block submerged with a thin knife blade, measure the depth of water, $\mathrm{I}_{2}$.

Allow the ice to melt, measure depth of water, $\mathrm{I}_{3}$.

Density of ice will be $\frac{1_{3}-I_{1}}{I_{2}-I_{1}}$

2. Measuring relative thermal conductivity of bubbly ice, in terms of thermal conductivity of normal ice (Fig. 8):

Take 2 identical tubes of metal-say $1 \frac{1}{2}$ in. diameter, ${ }_{10}^{1}$ in. wall, and $12 \mathrm{in}$. long $(4 \mathrm{~cm}$. $\times 3 \mathrm{~mm} . \times 30 \mathrm{~cm}$. $)$, their bottoms sealed like test tubes.

On a cold morning (temperature in night 2 or 3 degrees below freezing), bore holes in the bubbly and normal ice areas, to allow the two tubes to slide down to their lips in each hole.

Fill each tube with a strong brine mixture-ice, water and salt, and insert thermometer in each. Dilute brine in one or the other to give identical temperatures for both, say i $8^{\circ} \mathrm{F}$. ( $-8^{\circ} \mathrm{C}$. $)$.

Insert tubes filled with this brine into the two holes, one tube in bubbly ice the other in normal ice. Read both thermometers at regular intervals, noting temperatures, and plot temperatures against time elapsed from start. In some hours the two temperatures, rising ever slower, and rising at different rates, should level off to that of the surrounding ice, but the tube in the bubbly ice will be much slower in reaching that steady state temperature than the one in solid ice.

Plot the two graphs on co-ordinate paper; the ratio of the areas enclosed by the two graphs will be approximately the ratio of the thermal conductivities of the two ices.

(This thermal conductivity experiment loses its accuracy if liquid water (necessarily in varying amount) is in contact with outside of tube- therefore this experiment must be performed on a cold morning when no melt water is present-nor can the suggested quicker method of using hot water in the tube, to let it cool to freezing point, be employed; that would produce melt water outside the tube, however cold the ice.)

Repeating these two experiments several times will give a basis of the available degree of accuracy-it will be found that each set of experiments can be well within reasonable limits of variation, even on the open glacier. 
The greater albedo of bubbly white ice speaks for itself.

There are, of course, countless examples of ice falls whose outflowing glaciers show no ogives. In every case it will be found that either the ice fall was less than "extremely active", or started well above firn line. See, for instance, Figure 7 (p. 59) where neither the ice fall on left (Gorner) nor that on right (Grenz) develops ogives. Neither is active enough and also both are above firn line.

At times a few weakly developed quasi-ogives will be found as described on the Aletschgletscher by H. Godwin (I949) and also by King and Lewis (I96I). Similar quasi-ogives were also found once on the Victoria Glacier, Lake Louise, Alberta. In both cases it is my clear conclusion that these were localized examples of annual névé layering, more usual only at high latitudes where long-lived extremes between long hours of daylight summer warmth and complete absence of melting during the whole winter exaggerate seasonal sedimentation of snow. On the Aletschgletscher and (formerly) on the Victoria Glacier, annual steep-slope seasonal avalanches above seem to have predisposed them towards localized "layering", conditions which would agree with reported pollen examinations. Pollen support for the summer origin for dark layers in layering, and the diagnosed summer origin for dark bands in Forbes type ogives, are then purely coincidental. Moreover, these Aletsch and Victoria bands, by their non-continuity, indicate very special, local nearby origins.

My overall conclusion, agreeing with the conclusion of Dr. King and Mr. Lewis, is that the attenuation of ice in passage in the ice fall accentuates crystal growth, to become the dark bands (summer process).

Amplifying their view, and of very special influence, however, I conclude that ice in passage through the ice fall is likewise equally broken up in winter; its thorough aeration makes it so cold in winter as to mimic, on reconsolidation, the firnification process of cold Arctic snow, reconsolidating in winter into white bubbly, less dense ice and causing it to become the white bands. Without the dominant winter process, bubbly ice of the white bands could never be produced.

Taking a cue from a lane of similar white bubbly ice in the Gornergletscher, I conclude that the waves found at the foot of an ice fall are due to the same cause as compels this lane of white ice on the Gorner to ride higher than its flanking areas of normal ice. Presumably its lesser thermal conductivity together with its greater albedo are the factors protecting it from surface ablation.

MS. received ${ }_{15}$ July $196 \mathrm{I}$

\section{REFERENCES}

Fisher, J. E. I950. Ice pyramids on glaciers. Journal of Glaciology, Vol. I, No. 7, p. 373-77.

Godwin, H. 1949. Pollen analysis of glaciers in special relation to the formation of various types of glacier bands. Journal of Glaciology, Vol. 1, No. 6, p. 325-33.

King, C. A. M., and Lewis, W. V. 1961. A tentative theory of ogive formation. Journal of Glaciology, Vol. 3, No. 29, p. 91 2-39. 